Artikel Penelitian

\title{
Efek Propolis dan Jeruk Nipis terhadap Pertumbuhan Bakteri Staphylococcus Aureus dan Streptococcus Pyogenes secara In Vitro
}

Mitra Nofembri $Y^{1}$, Netti Suharti ${ }^{2}$, Mohamad Reza $^{3}$

\begin{abstract}
Abstrak
Penggunaan antibiotik yang irasional dapat menyebabkan terjadinya resistensi bakteri. Tujuan penelitian ini adalah untuk menentukan efek propolis dan jeruk nipis terhadap pertumbuhan bakteri Staphylococcus aureus dan Streptococcus pyogenes. Penelitian ini dilakukan di Laboratorium Mikrobiologi Fakultas Kedokteran Universitas Andalas Padang pada bulan Desember 2014 hingga April 2015. Rancangan penelitian bersifat eksperimental. Berdasarkan hasil penelitian diameter rerata daerah bebas kuman $S$. aureus yang diberikan propolis adalah $11 \mathrm{~mm}$ dan jeruk nipis $14,66 \mathrm{~mm}$. Diameter rerata daerah bebas kuman $S$. pyogenes yang diberikan jeruk nipis adalah 12,66 $\mathrm{mm}$. Sedangkan, propolis tidak dapat menghambat pertumbuhan bakteri $S$. pyogenes. Data dianalisis secara statistik dengan menggunakan uji Kruskal Wallis kemudian dilanjutkan dengan uji Mann Whitney. Hasil uji Mann Whitney antara propolis dan jeruk nipis terhadap pertumbuhan bakteri $S$. aureus menunjukkan perbedaan yang tidak bermakna $(p=0.05)$, sedangkan terhadap pertumbuhan bakteri $S$. pyogenes menunjukkan perbedaan yang bermakna $p=0,014$ $(p<0,05)$. Simpulan penelitian ini adalah propolis memiliki efek antibakteri terhadap pertumbuhan $S$. aureus dan tidak memiliki efek antibakteri terhadap pertumbuhan bakteri $S$. pyogenes, sedangkan jeruk nipis memiliki efek antibakteri terhadap pertumbuhan bakteri S. aureus dan S. pyogenes.
\end{abstract}

Kata kunci: propolis, jeruk nipis, S. aureus, S. pyogenes, efek antibakteri

\begin{abstract}
Irrational use of antibiotics could lead to bacterial resistance. The objective of this study was to find out the effects of propolis and lime (citrus aurantifolia) on the growth of $S$. aureus and S. pyogenes. It took place in the Laboratorium of Microbiology at the University of Andalas Padang, from December 2014 to April 2015. The design of this research was experimental. Based on the research's result, the average diameter of S. aureus bacteria-free zones that were given propolis is $11 \mathrm{~mm}$, and those which were given the lime water has 14.66 average diameter. The average diameter of $S$. pyogenes bacteria-free zones which given the lime water is $12.66 \mathrm{~mm}$. Meanwhile, propolis was unable to inhibit the growth of S. pyogenes. The datas were analyzed statistically with Kruskal Wallis test then continued with Mann Whitney test. The results of Mann Whitney test between propolis and lime water towards $S$. aureus growth showed insignificant difference $(p=0.05)$, while $S$. pyogenes showed significant difference $p=0.014(p$ $<0.05)$. The conclusion of this research is that propolis has the antibacterial effect on the growth of $S$. aureus and no effect on S. pyogenes growth. The lime has antibacterial effect o the growth of S. aureus and S. pyogenes.
\end{abstract}

Keywords: propolis, lime, S. aureus, S. pyogenes, antibacterial effect 
Affiliasi penulis: 1. Prodi Profesi Dokter FK Unand (Fakultas Kedokteran Universitas Andalas), 2. Bagian Mikrobiologi FK Unand, 3. Bagian Biologi FK Unand

Korespondensi: Mitra Nofembri Y, Email :

nofembrimitra@yahoo.com,Telp: 081372448724

\section{PENDAHULUAN}

Antibiotik merupakan golongan obat yang paling banyak digunakan di dunia terkait tingginya angka kejadian infeksi bakteri. Penggunaan antibiotik yang irasional dapat menyebabkan terjadinya resistensi bakteri yaitu menggunakan antibiotik tidak sesuai dosis, lama konsumsi tidak tepat, peresepan tidak sesuai diagnosis serta pengobatan sendiri dengan antibiotik yang seharusnya dengan resep dokter. Berdasarkan hasil Riskesdas 2013 didapatkan bahwa penggunaan antibiotik tanpa resep di Indonesia adalah $86,1 \%$. Angka kejadian tertinggi terjadi di Kalimantan Tengah 93,4 \% dan terendah di Gorontalo $74,7 \%$ sementara di Sumatera Barat $85,2{ }^{1}$

Beberapa bakteri yang resisten terhadap antibiotik adalah $S$. aureus dan $S$. pyogenes. $S$. aureus yang diisolasi dari beberapa rumah sakit di Asia pada awal tahun 2010 diperkirakan 28\% merupakan MRSA (Methichilin-Resistant Staphylococcus aureus) yang berasal dari rumah sakit di Hong Kong dan Indonesia dan lebih dari $70 \%$ berasal dari rumah sakit di Korea. Berdasarkan penelitian yang dilakukan oleh Muhammad pada bulan Januari hingga Juli 2010 di RSUD Surakarta didapatkan hasil bakteri yang resisten terhadap antibiotik golongan aminoglikosida dari berbagai spesimen. Angka tertinggi resistensi bakteri terhadap eritromisin pada spesimen darah diperlihatkan oleh kuman Staphylococcus sp36\%. Pada spesimen sputum angka tertinggi resistensi terhadap eritromisindiperlihatkan oleh kuman Streptococcus sp70\%, Proteus sp68\% dan Staphylococcus sp59\%. Pada spesimen pus angka tertinggi resistensi terhadap gentamisin diperlihatkan oleh kuman Staphylococcus sp $70 \%{ }^{2,3}$

Tingginya angka kejadian resistensi terhadap antibiotik maka penelitian senyawa yang dapat berfungsi sebagai antibakteri perlu dilakukan. Beberapa senyawa antibakteri yang berasal dari alam yang dapat digunakan adalah propolis dan jeruk nipis.
Propolis dapat menghambat pertumbuhan bakteri gram positif maupun bakteri gram negatif. Strain bakteri yang resisten terhadap penisilin, tetrasiklin dan eritromisin memiliki sensitivitas terhadap propolis. Penelitian yang dilakukan pada sapi yang mengalami mastitis didapatkan isolat Staphylococcus sp dan Streptococcus sp. Kedua bakteri tersebut memiliki sensitivitas yang tinggi terhadap ekstrak propolis. Selain itu, propolis juga memiliki daya hambat terhadap pertumbuhan bakteri $S$. aureus lebih besar dibandingkan dengan madu. Propolis dapat menghambat pertumbuhan bakteri dengan cara menghambat proses pembelahan sel, mengubah permeabilitas membran dinding sel dan menghambat sintesis protein sehingga menyebabkan bakteriolisis. ${ }^{4,5}$

Tidak hanya pada propolis, jeruk nipis juga memiliki efek antibakteri. Air perasan buah jeruk nipis dapat mencegah pertumbuhan bakteri $S$. aureus, $S$. haemolyticus, dan E. coli. Berdasarkan penelitian terbukti bahwa air perasan buah jeruk nipis dengan konsentrasi yang tinggi dapat memberikan daya hambat paling tinggi terhadap S. aureus. ${ }^{6}$

Peningkatan kejadian resistensi $S$. aureus dan S. pyogenes terhadap antibiotik dan ditemukannya bahan alami yang mengandung senyawa antibakteri maka perlu dilakukan penelitian mengenai efek propolis dan jeruk nipis terhadap pertumbuhan bakteri S. aureus dan S. pyogenes secara in vitro.

\section{METODE}

Penelitian telah dilakukan di Laboratorium Mikrobiologi Fakultas Kedokteran Universitas Andalas pada bulan Desember 2014 hingga April 2015. Penelitian ini bersifat eksperimental. Variabel adalah air perasan buah jeruk nipis, propolis cair, bakteri $S$. aureus dan S. pyogenes. Alat yang digunakan adalah cawan petri, tabung reaksi, botol steril, jarum ose, lampu spiritus, pinset, spuit, autoklaf, inkubator, lidi kapas steril, mistar, pisau, dan talenan. Bahan yang digunakan adalah air perasan buah jeruk nipis, Melia Propolis ${ }^{\circledR}$, biakan S. aureus dan S. pyogenes, agar darah. Agar $\mathrm{MH}$ II, aquades steril, amoksisilin, dan $\mathrm{NaCl}$ 0,9\%. Data hasil penelitian kemudian diolah secara statistik dengan menggunakan uji Kruskall Wallis karena sebaran data tidak normal. Hasil uji itu 
didapatkan nilai yang bermakna $(p<0,05)$, maka analisis data dilanjutkan dengan uji Mann Whitney.

\section{HASIL}

Tabel 1. Hasil uji sensitivitas $S$. aureus dengan menggunakan kontrol negatif, propolis, jeruk nipis, dan kontrol positif

\begin{tabular}{lllll}
\hline Perlakuan & \multicolumn{3}{c}{ Pengulangan } & Diameter $(\mathbf{m m})$ \\
& I & II & III & rerata \pm SD \\
\hline A (Aquades) & - & - & - & - \\
B (Propolis) & 10 & 11 & 12 & $11 \pm 0,82$ \\
C (Jeruk Nipis) & 13 & 16 & 15 & $14,66 \pm 1,25$ \\
D (Amoksisilin) & 16 & 16 & 16 & $16 \pm 0$ \\
\hline
\end{tabular}

Pada Tabel 1 dan Gambar 1 dapat dijelaskan bahwa rerata diamater daerah bebas kuman yang diberi amoksisilin sebagai kontrol positif terhadap pertumbuhan bakteri $S$. aureus adalah $16 \mathrm{~mm}$ sedangkan dengan menggunakan kontrol negatif tidak didapatkan diameter daerah bebas kuman.

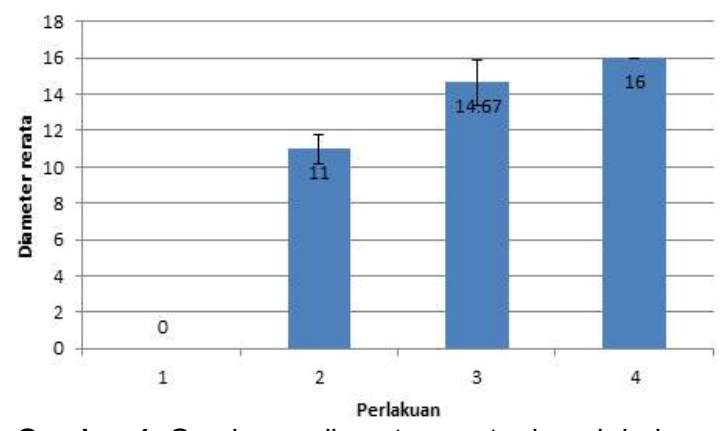

Gambar 1. Gambaran diameter rerata daerah bebas kuman S. aureus

Perlakuan dengan pemberian propolis didapatkan rerata diameter daerah bebas kuman pertumbuhan bakteri $S$. aureus adalah $11 \mathrm{~mm}$ sedangkan dengan pemberian air perasan buah jeruk nipis diameternya adalah $14,66 \mathrm{~mm}$.

Tabel 2. Hasil Uji sensitivitas S. pyogenes

\begin{tabular}{|c|c|c|c|c|}
\hline \multirow[t]{2}{*}{ Perlakuan } & \multicolumn{3}{|c|}{ Pengulangan } & \multirow{2}{*}{$\begin{array}{c}\text { Diameter }(\mathrm{mm}) \\
\text { rerata } \pm S D\end{array}$} \\
\hline & I & II & III & \\
\hline A (Aquades) & - & - & - & - \\
\hline B (Propolis) & - & - & - & - \\
\hline C (Jeruk Nipis) & 11 & 15 & 12 & $12,66 \pm 2,08$ \\
\hline D (Amoksisilin) & 43 & 43 & 42 & $42,66 \pm 0,58$ \\
\hline
\end{tabular}

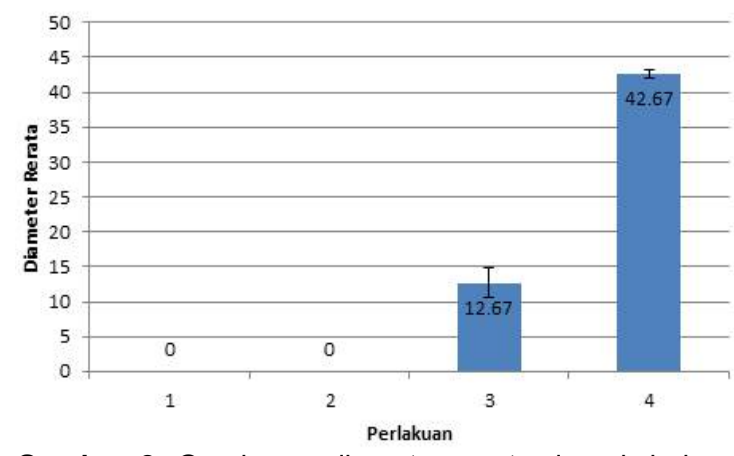

Gambar 2. Gambaran diameter rerata daerah bebas kuman S. pyogenes

Tabel 2 dan Gambar 2 menjelaskan bahwa rerata diamater daerah bebas kuman yang diberi amoksisilin sebagai kontrol positif terhadap pertumbuhan bakteri $S$. pyogenes adalah 42,66 mm sedangkan dengan menggunakan kontrol negatif dan propolis tidak didapatkan diameter daerah bebas kuman pertumbuhan bakteri $S$. pyogenes. Pada perlakuan dengan pemberian air perasan buah jeruk nipis didapatkan rerata diameter daerah bebas kuman pertumbuhan bakteri $S$. pyogenes adalah 12,66 mm.

\section{PEMBAHASAN}

Propolis dan jeruk nipis memiliki daya hambat terhadap pertumbuhan bakteri $S$. aureus, hal ini sesuai dengan penelitian yang dilakukan oleh Bangun Azhari Yusuf yang menunjukkan efek antibakteri propolis cair terhadap S. aureus dan penelitian Razak et al pada yang menunjukkan efek antibakteri air perasan buah jeruk nipis terhadap $S$. aureus. Propolis dan jeruk nipis dapat menghambat pertumbuhan bakteri $S$. aureus karena mengandung bahan-bahan yang memiliki efek antibakteri, salah satunya adalah flavonoid. ${ }^{6,7}$

Jeruk nipis memilki efek antibakteri terhadap pertumbuhan bakteri $S$. pyogenes sementara propolis tidak memilki efek antibakteri terhadap pertumbuhan bakteri $S$. pyogenes. Penelitian yang dilakukan oleh Hardoko dan Yuliana membuktikan bahwa campuran jus jeruk nipis dan madu yang dipanaskan hinga suhu $100^{\circ}$ C memberikan efek antibakteri terhadap pertumbuhan bakteri $S$. aureus dan $S$. pyogenes. Selain itu, penelitian Ophori dan Wemabu di Nigeria 
membuktikan bahwa ekstrak etanol propolis memberikan efek antibakteri terhadap pertumbuhan bakteri $H$. influenza, S. pneumonia, $M$. catarrhalis dan S. pyogenes. ${ }^{8,9}$

Propolis cair yang digunakan dalam penelitian ini tidak memberikan efek antibakteri terhadap $S$. pyogenes. Hal ini disebabkan karena perbedaan jenis tumbuh-tumbuhan, jenis lebah yang terdapat dalam suatu wilayah, resistensi bakteri dan metode penelitian yang digunakan.

Berdasarkan diameter rerata daerah bebas kuman $S$. aureus dan S. pyogenes, jeruk nipis memiliki daya hambat yang lebih kuat jika dibandingkan dengan propolis. Hal ini disebabkan karena perbedaan kadar flavonoid, keasaman, dan bahan-bahan lain yang dapat mempengaruhi efek antibakteri propolis dan jeruk nipis. Propolis dengan $\mathrm{pH}$ yang lebih asam memiliki daya hambat lebih besar dibandingkan dengan $\mathrm{pH}$ basa. Bentuk sediaan juga mempengaruhi efek antibakteri yang dihasilkan. Propolis tersedia dalam bentuk ekstrak, cair dan padat. Berdasarkan penelitian propolis dalam bentuk padat memiliki efek antibakteri yang lebih besar dibandingkan dengan propolis cair. ${ }^{10,11}$

Hasil uji statistik didapatkan perbedaan bermakna antara pemberian propolis dan jeruk nipis terhadap pertumbuhan bakteri $S$. pyogenes. Sedangkan, tidak terdapat perbedaan bermakna hasil diameter daerah bebas kuman $S$. aureus antara pemberian propolis dan jeruk nipis, hal ini bisa disebabkan karena keterbatasan penelitian dengan menggunakan satu isolat bakteri dan tiga kali pengulangan. Selain itu, walaupun propolis memiliki efek sebagai antibakteri, penggunaan propolis harus tetap diperhatikan karena salah satu kandungan propolis adalah polen atau serbuk sari. Serbuk sari merupakan alergen yang dapat memicu terjadinya reaksi alergi atau hipersensitivitas. ${ }^{12}$

\section{SIMPULAN}

Propolis memiliki daya hambat terhadap pertumbuhan bakteri $S$. aureus dan tidak memiliki daya hambat terhadap pertumbuhan bakteri $S$. pyogenes.
Jeruk nipis memiliki daya hambat terhadap pertumbuhan bakteri $S$. aureus dan S. pyogenes.

Jeruk nipis memiliki efek antibakteri yang lebih kuat terhadap pertumbuhan bakteri $S$. aureus dan $S$. pyogenes jika dibandingkan dengan propolis tetapi tidak bermakna berdasarkan uji statistik.

\section{UCAPAN TERIMA KASIH}

Terima kasih kepada Kepala Bagian dan staff Laboratotrium Mikrobiologi Fakultas Kedokteran Universitas Andalas yang telah membantu penulis dalam melakukan peneltian ini.

\section{DAFTARPUSTAKA}

1. Badan Penelitian dan Pengembangan Kesehatan. Riset kesehatan dasar. Jakarta: Departemen Kesehatan Republik Indonesia; 2013.

2. Chen CJ, Huang YC. New epidemiology of Staphylococcus aureus infection in Asia. Clinical Microbiology Infection. 2014; 20:605-23.

3. Muhammad Syaiful SN. Hubungan pola kuman dan penggunaan antibiotik aminoglikosida di RSUD Dr. Moewardi Surakarta (skripsi). Surakarta: Universitas Sebelas Maret; 2007.

4. Lotfy M. Biological activity of bee propolis in health and disease. Asian Pacific Journal of Cancer Prevention. 2006;7:22-31.

5. Rahman MM, Allan R, Muhammad SA. Antibacterial activity of propolis and honey against Staphylococcus aureus and Escherichia coli. African Journal of Microbiology Research. 2010; 16(4):1872-8.

6. Razak A, Aziz, D, Gusti, R. Uji daya hambat air perasan buah jeruk nipis (Citrus aurantifolia s.) terhadap pertumbuhan bakteri Staphylococcus aureus secara in vitro. Jurnal Kesehatan Andalas. 2013;2(1):5-8.

7. Yusuf BA. Perbedaan daya hambat bakteri dari propolis cair yang ada di pasaran terhadap E. coli dan S. aureus secara in vitro (skripsi). Padang: Universitas Andalas; 2013.

8. Hardoko, Yuliana. Study of antibacterial activity of mixed lime juice and honey of heating temperature on Staphylococcus aureus and Streptococcus 
pyogenes. International Journal of Pure and Applied Sciences and Technology. 2014;21(2):1-7.

9. Ophori EA, Wemabu EC. Antimicrobial activity of propolis extract on URT infections in pediatric patients admitted to Al-Thowrah Hospital, Hodeidah City, Yemen. World Journal of Medical Sciences. 2012;7(3):172-7.

10. Ivancajic S, Mileusnic I, Desanka CM. In vitro antibacterial activity of propolis extract on 12 different bacteria in conditions of 3 various values. Archives of Biological Science. 201062(4):915-34.

11. Putra AA. Perbedaan efek antibakteri propolis cair dan propolis padat yang ada di pasaran terhadap Staphylococcus aureus secara in vitro (skripsi). Padang: Universitas Andalas; 2014.

12. Baharuddin. Respon imun pada hipersensitivitas tipe i yang disebabkan oleh serbuk sari (makalah Immunologi). Surabaya: Universitas Airlangga; 2012. 